\title{
Model Pengembangan Koperasi Unit Desa (KUD) Berbasis Agribisnis di Pedesaan Swapraja Biboki
}

Sirilius Nafanu ${ }^{\text {a }}$

${ }^{a}$ Fakultas Ekonomi dan Bisnis, Universitas Timor, Kefamenanu, TTU - NTT, Indonesia

\section{Article Info}

\section{Article history:}

Received 27 Desember 2015

Received in revised form 12 Januari 2015

Accepted 11 Maret 2016

Keywords:
Koperasi Unit Desa
Swapraja

Swapraja

Biboki

\begin{abstract}
Abstrak
Penelitian ini bertujuan untuk mengetahui model pengembangan koperasi unit desa (KUD) berbasis agribisnis di pedesaan swapraja Biboki. Penelitian dilaksanakan di Kecamatan yang memiliki Lembaga KUD yaitu Kecamatan Biboki Utara, Biboki Selatan dan biboki Anleu. Data dalam penelitian ini terdiri dari data primer dan data sekunder. Hasil penelitian menunjukkan bahwa dalam pembangunan KUD di swapraja Biboki untuk percepatan ekonomi daerah, sangat perlu adanya kemitraan. Kemitraan yang dimaksud adalah dalam bentuk partisipasi dari semua unsur yang terkait untuk pengembangan KUD. Pembangunan koperasi didasari oleh adanya potensi di daerah yang dapat mendukung berjalannya KUD, antara lain: masyarakat tani, pengusaha kecil dan industri rumah tangga. Peran serta pihak swasta, yaitu perusahaan-perusahaan besar sangat diperlukan untuk mengisi dan melengkapi berbagai program pemerintah. Pihak pengusaha yang berada pada posisi yang kuat dapat membantu KUD pada posisi yang lemah dalam bentuk jaringan kemitraan. Hubungan ini dapat memberikan keuntungan kepada KUD, yaitu: transfer teknologi yang lebih unggul; memperoleh informasi dan peluang pasar secara cepat; dapat membuka akses terhadap modal dan pasar; serta adanya jaminan dan kepastian pasar bagi produk industri kecil dan industri rumah tangga. (02016 dipublikasikan oleh Agrimor.
\end{abstract}

\section{Pendahuluan}

Pemerintah Daerah Kabupaten Timor Tengah Utara (TTU) dalam memacu pertumbuhan ekonomi mencanangkan pembangunan melalui gerakan cinta petani. Gerakan ini dilakukan untuk memanfaatkan potensi daerah dengan model pengelolaan yang berkelanjutan. Potensi yang dimiliki antara lain pengembangan tanaman hortikultura; perkebunan; usaha perikanan; peternakan; pertambangan; sektor industri dan keparawisataan.

Pengembangan sektor pertanian dalam arti luas harus diarahkan kepada sistem agribisnis, karena pendekatan ini akan dapat meningkatkan nilai tambah, yang pada hakekatnya dapat meningkatkan pendapatan bagi pelaku-pelaku agribisnis di daerah. Oleh karena itu, dalam pemberdayaan ekonomi rakyat, keberpihakan pada pembangunan sektor agribisnis perlu disertai dengan suatu mekanisme yang menjamin bahwa manfaat pembangunan dapat dinikmati oleh rakyat.

Ketertinggalan pada sektor pertanian khususnya di pedesaan Swapraja Biboki disebabkan kebijakan masa lalu yang melupakan sektor pertanian sebagai dasar keunggulan komparatif maupun kompetitif. Pembangunan ekonomi yang berbasis kerakyatan harus dimulai dari ekonomi pedesaan, karena di pedesaan itu sebagian besar penduduk mencari nafkah dari sektor pertanian. Untuk memajukan ekonomi di daerah sebagai percepatan pembangunan ekonomi yang berbasis kerakyatan, maka perlu dikembangkan Koperasi Unit Desa (KUD) sebagai sokoguru perekonomian masyarakat. Berkembangnya KUD di daerah diharapkan dapat memberikan kontribusi terhadap pembangunan ekonomi di daerah pedesaan. Untuk itu, perlu dilakukan suatu kajian yang dapat memberikan masukan dalam kaitan dengan kebijakan pengembangan KUD di Pedesaan Swapraja Biboki.

Pengolahan hasil pertanian masyarakat di Pedesaan Swapraja Biboki pada umumnya dalam bentuk usaha kecil dan industri rumah tangga. Dari sisi proses produksi mereka sangat terbatas dalam penguasaan teknologi dan kekurangan modal untuk pengembangan skala usahanya. Begitu juga kekuatan tawar menawar dari hasil produknya sangat rendah. Salah satu untuk meningkatkan kekuatan tawar menawar masyarakat pedesaan adalah melalui lembaga ekonomi pedesaan yaitu Koperasi Unit Desa (Perindagkop TTU, 2012).

Menurut Wijaya. S (2002), manfaat berkoperasi adalah: 1) membantu meningkatkan standar sosial ekonomi di daerah dengan memanfaatkan potensi dan penyerapan tenaga kerja; 2) bermanfaat langsung, karena sesuai dengan kehidupan masyarakat pedesaan; dan 3) ekonomi pedesan bisa tumbuh karena koperasi berakar kuat di pedesaan.

Pemberdayaan masyarakat pedesaan juga harus mampu memberikan perlindungan yang jelas terhadap masyarakat. Dalam pemberdayaan ekonomi masyarakat pedesaan, sektor pertanian harus menjadi sasaran utama. Sektor ini harus dijadikan pijakan yang kokoh sehingga di pedesaan bisa tercapai swasembada berbagai produk pertanian, terutama pangan, sebelum memasuki era industrialisasi. Lebih spesifik, ketahanan pangan lokal harus tercapai lebih dahulu (Basri. M, 2007)

Dinamika pertumbuhan Koperasi di TTU terus dipacu dari waktu ke waktu. Hingga penghujung tahun 2014 Koperasi yang tercatat di Dinas Koperasi dan UMKM TTU sebanyak 82 unit koperasi yang menyebar di sejumlah Kecamatan yang ada di Kabupaten TTU dengan rincian 13 unit dalam bentuk KUD Sedangkan di Swaparaja Biboki yang meliputi 6 Kecamatan tercatat 3 KUD, yaitu KUD Manufui (Kecamatan Biboki Selatan), KUD Lurasik (Kecamatan Biboki Utara) dan KUD Tamkesi (Kecamatan Biboki Anleu). Hal tersebut menunjukkan perkembangan KUD yang ada di Swapraja Biboki masih jauh dari harapan. Jumlah KUD masih kurang, sementara aspek kualitas kehadiran KUD di Swapraja Biboki belum tampil profesional sebagaimana yang diharapkan masyarakat.

Berdasarkan permasalahan di atas, penulis tertarik untuk melakukan penelitian yang diaktualisasikan dalam judul model pengembangan KUD berbasis agribisnis di pedesaan Swapraja Biboki yang bertujuan menemukan model pembangunan ekonomi pedesaan melalui pengembangan KUD berbasis agrobisnis.

\section{Metode}

Penelitian dilaksanakan di Kecamatan yang memiliki Lembaga KUD yaitu Kecamatan Biboki Utara, Biboki Selatan dan biboki Anleu. Data dalam penelitian ini terdiri dari data primer dan data sekunder. Data primer adalah data yang diperoleh lansung dari sumber utama yaitu pelaku bisnis di daerah terutama dalam kegiatan koperasi, pemuka masyarakat, birokrasi di pedesaan. Teknik yaitu suatu pendekatan partisipatif untuk mendapatkan data/informasi dan penilaian (assesment) secara umum di lapangan.

\section{Hasil dan Pembahasan}

\subsection{Permasalahan Koperasi di Pedesaan Swapraja Biboki}

Dari hasil pengamatan di lapangan ditemukan permasalahan pengembangan koperasi, antara lain: 1) pada penentuan kepengurusan dan manajemen koperasi masih dipengaruhi oleh teposeliro, bukan didasarkan pada kualitas kepemimpinan dan kewirausahaan; 2) kegiatan koperasi tidak sesuai dengan kebutuhan anggota sehingga koperasi berjalan atas kehendak pengurus semata. Ini berakibat kepada rendahnya partisipasi anggota karena anggota tidak merasakan manfaat sebagai anggota koperasi; 3 ) masih ditemukan koperasi tidak melibatkan anggota dalam aktifitasnya (koperasi dikendalikan oleh pemilik modal); 4) adanya kegiatan koperasi yang memanfaatkan dukungan pemerintah terhadap keberadaan koperasi bagi kepentingan pribadi; 5) usaha yang dilakukan tidak fokus, sehingga tingkat profitabilitas koperasi masih rendah. Akibatnya pengembangan aset koperasi sangat lambat dan koperasi sulit untuk berkembang; 6) masih lemahnya sistem informasi di tingkat koperasi, terutama informasi harga terhadap komoditas pertanian sehingga akses pasar produk pertanian dan produk lainnya masih relatif sempit; 7) belum berperannya koperasi sebagai penyalur sarana produksi pertanian di pedesaan dan sebagai penampung hasil produksi pertanian.

Disamping temuan berbagai permasalahan diatas, hasil pengamatan di lapangan juga ditemukan beberapa faktor pendukung pembangunan ekonomi daerah melalui pengembangan koperasi, antara lain: 1) potensi masyarakat; 2) pengusaha; 3) lembaga perkreditan; 4) instansi terkait; dan 5) koperasi sebagai badan usaha, (Hendrajogi, 2007).

\subsection{Kebijakan Pembangunan Koperasi Unit Desa}

KUD merupakan jenis usaha yang digolongkan dalam ekonomi kerakyatan karena sifatnya mandiri dan merupakan usaha bersama. Ketahanan ekonomi daerah tergantung pada pelaku-pelaku ekonomi, termasuk kinerja KUD. Untuk itu, kekuatan ekonomi rakyat akan dapat tumbuh dan berkembang dengan baik apabila ada sinergi kolektif yang dinaungi oleh KUD berjalan sebagaimana mestinya.

Koperasi di Kabupaten Timor Tengah Utara pada tahun 2014 berjumlah 82 unit dengan rincian jenis KUD berjumlah 13 unit sedangkan non KUD tercatat 69 unit. Sedangkan total koperasi di swapraja Biboki terdapat 8 unit dengan rincian KUD sebanyak 3 unit dan 5 unit non KUD. Kondisi semacam in sangat memprihatinkan. Betapa tidak, dari 6 kecamatan yang ada di swapraja Biboki hanya tercatat 3 unit KUD di Kecamatan Biboki Selatan, Biboki Utara, dan Biboki Anleu.

Kehidupan KUD diupayakan untuk terus dikembangkan jumlahnya minimal perkecamatan satu unit KUD. Lebih dari itu, kedepan pemerintah perlu mengembangkan KUD melalui pembinaan pengembangan KUD secara khusus dalam pelaksanaan ekonomi kerakyatan guna peningkatan pendapatan dan kesejahteraan serta kegiatan-kegiatan produktif yang mempunyai nilai tambah; KUD melalui perluasan wawasan pengetahuan, organisasi, manajemen usaha, dan pengalaman untuk meningkatkan kualitas pelayanan kepada anggota masyarakat sehingga dapat meningkatkan keyakinan masyarakat dan dunia usaha lainnya untuk menanamkan investasi pada KUD, (Nafanu, S. 2011). pengumpulan data dilakukan dengan metode Rapid Rural Apprasial (RRA), Meningkatkan dan mengembangkan ekonomi produktif dan efisien dalam bentuk 


\subsection{Strategi Pengembangan KUD}

Pengembangan KUD tidak terlepas dari perkembangan usaha masyarakat pedesaan. Sebagian besar KUD yang ada jenis usahanya adalah pertanian dan industri rumah tangga. Pembangunan ekonomi pedesaan di masa datang tidak terlepas dari pengembangan usaha yang berbasis ekonomi pedesaan, dalam hal ini akan dikembangkan melalui KUD. Karakteristik yang melekat pada KUD bisa merupakan kelebihan atau kekuatan yang potensial, di sisi lain pada kekuatan tersebut terkandung kelemahan yang justru menjadi penghambat perkembangannya. Kombinasi dari kekuatan dan kelemahan serta intereaksi keduanya dengan situasi ekternal akan menentukan prospek perkembangan UKM.

Dengan adanya kriris ekonomi, menyebabkan pemerintah dan para pengambil kebijaksanaan kembali berpikir ulang tentang arah perekonomian yang selama ini ditempuh. Kini timbul kemauan politik yang kuat untuk membenahi inefisiensi dan mis-alokasi sumberdaya (misallocation of resources) yang terjadi di sektor ril yang selama ini dibiarkan saja terjadi karena kuatnya vested interest para pemburu rente yang menguasai birokrasi pemerintahan. Akibat dari mis-alokasi sumberdaya adalah terabaikannya pembangunan KUD yang berbasis sumberdaya alam serta sumberdaya pertanian (resource based industries).

Banyak industri yang dibangun membutuhkan bahan baku dan komponen yang harus diimpor atau industri-industri yang tidak banyak terkait dengan perekonomian lokal sehingga industri ini sangat rentan terhadap gejolak mata nilai uang. Industri-industri jenis ini pada umumnya adalah industri yang berpihak kepada golongan ekonomi kuat (Syahza. A, 2007).

Manifestasi tujuan pengembangan ekonomi kerakyatan dapat dilakukan terutama melalui KUD. Salah satu cara untuk mencapai tujuan tersebut adalah pengembangan KUD yang terencana dengan baik dan terkait dengan pembangunan sektor ekonomi lainnya terutama di pedesaan.

\subsection{Pengembangan Koperasi Melalui Kemitraan}

Kemitraan merupakan bagian tanggungjawab sosial perusahaan terhadap lingkungannya sesuai dengan konsep manajemen partisipatif. Pagelaran kemitraan tidak hanya dilakukan sebagai belas kasihan oleh yang kuat terhadap yang lemah, tetapi seyogyanya terjalin karena kehendak bisnis yang dibarengi dengan rasa tanggung jawab sosial yang kuat.

Dalam era kompetisi yang kompetitif, keberadaan KUD dituntut untuk dapat bersaing dengan pelaku usaha lainnya sebagai wujud pemberdayaan ekonomi rakyat. Langkah kerjasama dalam bentuk kemitraan usaha merupakan suatu strategi untuk dapat mengembangkan KUD dan secara moril sangat diperlukan adanya dukungan yang maksimal dari pihak pengusaha besar melalui paket pembinaan. Harus diakui usaha KUD ini tidak terlepas dari tantangan dan hambatan, baik dari segi permodalan, sumberdaya manusia, manajemen, minimnya penguasaan teknologi informasi, iklim berusaha, dan distribusi jasa/produk yang dihasilkan.

Pembangunan KUD untuk percepatan ekonomi pedesaan, sangat perlu adanya kemitraan. Kemitraan yang dimaksud adalah dalam bentuk partisipasi dari semua unsur yang terkait untuk pengembangan KUD. Pembangunan KUD didasari oleh adanya potensi desa, antara lain: masyarakat petani, pengusaha kecil, industri rumah tangga. Dengan dasar kebutuhan bersama, potensi ini harus dikembangkan melalui KUD dan menjadi anggota KUD pada masing-masing jenis usaha atau kegiatannya. KUD dengan manajemen yang baik menjalin kerjasama dalam bentuk mitra kerja dengan lembaga keuangan dan perusahaan. Dari ketiga komponen mitra (koperasi, perusahaan, dan lembaga keuangan) perlu dukungan dari pihak pemerintah sebagai pembuat kebijakan. Pemerintah sifatnya disini hanya sebagai pemberian jasa berupa pembinaan dan penyuluhan.

\subsection{Paradigma Baru Pasar Bersama}

Upaya mengatasi masalah pemasaran produk petani dan industri rumah tangga, maka perlu dipikirkan paradigma baru sebagai tawaran solutif. Salah satu alternatif pemecahannya adalah memberdayakan lembaga ekonomi pedesaan yaitu KUD. Tanpa KUD tidak mungkin usaha petani dapat berkembang. KUD inilah yang akan berhubungan dengan pengusaha besar (Syahza. A, 2007). Melalui koperasi masalah yang dihadapi oleh pengusaha di daerah dapat teratasi.

KUD merupakan badan usaha di pedesaan dan pelaksana penuh sistem pemasaran produk yang dihasilkan oleh Petani. Dari sisi lain KUD juga merupakan pedagang perantara dari produk yang dihasilkan oleh anggotanya. KUD berfungsi sebagai lembaga pemasaran dari produk masyarakat desa. Dalam KUD dilakukan pengendalian mutu (sortiran, pengolahan, pengepakan, pemberian label, dan penyimpanan) sesuai dengan permintaan dan kebutuhan pasar. KUD juga berperan sebagai media informasi pasar, perkembangan harga, dan daya beli pasar.

Melalui informasi pasar, KUD harus dapat menciptakan peluang pasar produk masyarakat desa sehingga wong deso tidak ragu untuk melakukan kegiatan usahanya karena ada jaminan dari KUD bahwa produk mereka akan ditampung. Kegiatan ini akan merangsang partisipasi anggota terhadap KUD, yang pada hakikatnya terjadi kesinambungan usaha KUD. Investasi yang dilakukan oleh KUD berupa transportasi, mesin pengolah produk di pedesaan, mesin dan alat pengolah harus berupa penanaman modal atas nama anggota. Artinya setiap anggota mempunyai saham kepemilikan aset KUD. Dengan demikian konsep ekonomi kerakyatan di pedesaan dapat berkembang (Syahza. A, 2007).
KUD juga berperan sebagai penyedia kredit yang diperoleh dari lembaga perkreditan dan pengusaha. Pemberian kredit ini didasarkan kepada bentuk usaha yang mengembangkan komoditi potensial dan punya peluang pasar. Tingkat pengembalian kredit oleh pengusaha dapat dilakukan melalui pemotongan penjualan hasil kepada KUD. Kegiatan unit usaha ini akan menimbulkan multiplier effect ekonomi dalam kehidupan masyarakat.

Pada hakikatnya industri kecil dan industri rumah tangga sebagai unit usaha di pedesaan dapat menciptakan peluang usaha dalam kegiatan ekonomi sehingga menyebabkan naiknya pendapatan mayarakat yang pada akhirnya meningkatkan kesejahteraan masyarakat pedesaan. Selain yang diungkapkan di atas, KUD juga berfungsi sebagai: Pertama, mencarikan alternatif pemecahan masalah pengusaha kecil seperti penyediaan kredit, pembentukan modal bersama melalui tabungan, penyediaan sarana produksi, pelaku agroindustri, memasarkan produk dan sebagainya; Kedua, memberikan kemudahan berupa pelatihan dan pembinaan kepada pengusaha dalam usaha-usaha yang dilakukannya; dan ketiga, pengusaha di pedesaan perlu diorganisir untuk memperkuat posisi tawarmenawarnya dalam menghadapi persaingan dan melakukan kemitraan dengan pihak lain.

Dalam era globalisasi dan menyongsong liberalisasi perdagangan peranan pemerintah makin kecil, bahkan kebijaksanaan pajak impor dan subsidi akan dihapuskan bila sampai waktunya. Dengan demikian peran serta pihak swasta, yaitu perusahaan-perusahaan besar sangat diperlukan untuk mengisi dan melengkapi berbagai program pemerintah. Pihak pengusaha yang berada pada posisi yang kuat dapat membantu KUD pada posisi yang lemah dalam bentuk jaringan kemitraan. Hubungan ini dapat memberikan keuntungan kepada KUD, yaitu: transfer teknologi yang lebih unggul; memperoleh informasi dan peluang pasar secara cepat; dapat membuka akses terhadap modal dan pasar; serta adanya jaminan dan kepastian pasar bagi produk industri kecil dan industri rumah tangga.

\section{Simpulan}

Berlakunya otonomi daerah, dunia usaha khususnya KUD akan menghadapi suatu perubahan besar yang sangat berpengaruh terhadap iklim berusaha dan dinamika persaingan. Oleh sebab itu, KUD dituntut dapat beradaptasi menghadapi perubahan tersebut. Dalam pembangunan KUD untuk percepatan ekonomi daerah, sangat perlu adanya kemitraan. Kemitraan yang dimaksud adalah dalam bentuk partisipasi dari semua unsur yang terkait untuk pengembangan KUD. Pembangunan koperasi didasari oleh adanya potensi di daerah yang dapat mendukung berjalannya KUD, antara lain: masyarakat tani, pengusaha kecil dan industri rumah tangga.

Menyongsong liberalisasi perdagangan peranan pemerintah makin kecil, bahkan kebijaksanaan pajak impor dan subsidi akan dihapuskan bila sampai waktunya. Dengan demikian peran serta pihak swasta, yaitu perusahaanperusahaan besar sangat diperlukan untuk mengisi dan melengkapi berbagai program pemerintah. Pihak pengusaha yang berada pada posisi yang kuat dapat membantu KUD pada posisi yang lemah dalam bentuk jaringan kemitraan Hubungan ini dapat memberikan keuntungan kepada KUD, yaitu: transfer teknologi yang lebih unggul; memperoleh informasi dan peluang pasar secara cepat; dapat membuka akses terhadap modal dan pasar; serta adanya jaminan dan kepastian pasar bagi produk industri kecil dan industri rumah tangga.

\section{Pustaka}

Basri. Y. Z., 2003, Pemberdayaan Ekonomi Masyarakat Pedesaan, dalam Usahawan Indonesia No 03/TH.XXXII Maret 2003, Lembaga Manajemen, FE-UI, Jakarta: halaman 49-55.

Dinas Perindagkop Kabupaten Timor Tengah Utara, 2012.

Hendrajogi, 2007, Koperasi: Asas-Asas, Teori dan Praktek, PT. Radjagrafindo Persada, Jakarta.

Nafanu, S. 2011, Ekonomi Koperasi, Edisi Pertama, Absolute Media, Yogyakarta.

Syahza. A., 2007. Model Pemberdayaan Masyarakat dalam Upaya Percepatan Pembangunan Ekonomi Pedesaan Berbasis Agribisnis di Daerah Riau, DP2M Direktorat Jenderal Pendidikan Tinggi Departemen Pendidikan Nasional, Jakarta.

Wijaya, NHS. 2002. Membangun Koperasi dari Mimpi Buruknya, dalam Usahawan Indonesia XXXI (07): halaman 28-34. 